\title{
Institutional adaptive capacity and climate change response in the Congo Basin forests of Cameroon
}

\author{
H. Carolyn Peach Brown • Johnson Ndi Nkem • \\ Denis J. Sonwa • Youssoufa Bele
}

Received: 15 November 2009 / Accepted: 28 January 2010 /

Published online: 17 February 2010

(C) Springer Science+Business Media B.V. 2010

\begin{abstract}
Climate change presents additional challenges to a diverse country like Cameroon that shares the Congo Basin rainforest. Not only is the population vulnerable to the direct effects of climate change, forest-dependent communities are also vulnerable to changing environmental policy that may affect their access to forest resources. Using a qualitative approach to data collection through semi-structured interviews and content analysis of relevant documents, the perception of decision-makers within, and the response of the institutions of the state, the private sector and civil society to the complex challenges of climate change in the Congo Basin forest of Cameroon were analysed. Results indicate that while decision-makers' awareness of climate change is high, a concrete institutional response is at a very early stage. Cameroon has low adaptive capacity that is further constrained by weak linkages among government institutions nationally and between different levels of government and with communities. Civil society institutions play a role in enhancing government capacity to respond, particularly in relation to new international policies on climate change and forests. Adaptive capacity would be further enhanced by facilitating institutional linkages and coordinating multilevel responses across all boundaries of government, private sector and civil society. A collaborative capacity builder could foster the transfer, receipt and integration of knowledge across the networks, and ultimately build long-term collaborative problem-solving capacity in Cameroon.
\end{abstract}

H. C. P. Brown $(\square)$

Department of Geography, University of Guelph, Guelph, Ontario N1G 2W1, Canada e-mail: hcpbrown@uoguelph.ca

J. N. Nkem

Center for International Forestry Research (CIFOR), Bogor, Indonesia

e-mail: j.nkem@cgiar.org

D. J. Sonwa • Y. Bele

Center for International Forestry Research (CIFOR), Yaoundé, Cameroon

D. J. Sonwa

e-mail: d.sonwa@cgiar.org

Y. Bele

e-mail: b.youssoufa@cgiar.org 
Keywords Cameroon - Congo Basin forest · Climate change $\cdot$ Institutions $\cdot$ Perception · Adaptive capacity

\section{Introduction}

Predicted future changes in climate, with consequent impacts on ecosystems and physical systems, pose significant challenges for society. Forests are expected to face significant pressure from climate change over the next century which will potentially disrupt the important ecological, economic, social, and aesthetic services that forests provide to other natural systems and humankind (Intergovernmental Panel on Climate Change (IPCC) 2007b; Bonan 2008; Eastaugh 2008). Such future changes will have a strong impact on natural resource-dependent communities through a multitude of primary and secondary effects in both natural and social systems (Adger 2003b). According to the World Bank, more than 1.6 billion people worldwide depend on forests for their livelihoods, the majority of whom live in extreme poverty. Of that number it is estimated that 60 million indigenous people are totally dependent on forests, 350 million are highly forest dependent, and 1.2 billion are dependent on agroforestry (The World Bank 2008a).

In Africa, over two-thirds of the population of approximately one billion people, rely directly or indirectly on forests and woodlands for their livelihood, as well as medicinal plants and common pool forest resources for meeting essential fuel wood, grazing, and other needs (The World Bank 2004). Similar patterns of dependency are observed in the Congo Basin Forests whose over 30 million inhabitants, representing over 150 ethnic groups, depend on the forest for food, shelter, and other livelihood activities (Congo Basin Forest Partnership 2006). The vulnerability of tropical forest ecosystems to climate change represents a risk to the livelihoods of these forest-dependent communities and to the development of national economies. This vulnerability is exacerbated by historical and contemporary problems related to natural resource mismanagement, conflict and inequality (Annecke 2002; Dixon et al. 2003).

The Congo Basin Forests of central Africa represent a vast transboundary natural resource pool indispensable to the national development plans of the six countries of the region. ${ }^{1}$ Cameroon, which shares the Congo Basin, is dependent on the forest for a large part of its economy from industrial timber harvesting (Republic of Cameroon 2003; Whiteman and Lebedys 2006). Additionally, local communities depend on the forest for subsistence and commercial agriculture as well as the harvesting of non-timber forest products (NTFPs). The growing local and export markets for NTFPs provide a significant contribution to the livelihoods of poor forest dwellers and the urban and peri-urban unemployed (Ruiz Pérez et al. 2000; Shackleton et al. 2007).

As the second largest contiguous rainforest in the world, the Congo Basin represents a carbon reserve of global significance for regulating greenhouse gas emissions (Congo Basin Forest Partnership 2006; Hoare 2007). Therefore, opportunities from international policy on Reduced Emissions from Deforestation and Forest Degradation (REDD) to mitigate climate change through maintenance and restoration of forest carbon sinks, also have the potential to contribute to other goals. In particular, forest conservation under REDD could contribute to the maintenance of biodiversity as well as ecosystem services in forested areas (Hare and Macey 2008; Streck et al. 2008; Thompson et al. 2009). Conservation of forests would also

\footnotetext{
${ }^{1}$ Cameroon, Central African Republic, Democratic Republic of Congo, Equatorial Guinea, Gabon, Republic of Congo
} 
reduce the vulnerability of local forest-dependent communities to climate change and enable them to adapt (Locatelli et al. 2008). While still hotly debated, many feel that a 'propoor' REDD may represent a strategy for economic development and poverty reduction in developing countries (Luttrell et al. 2007; Brown et al. 2008a; Richards and Jenkins 2007). Beyond the potential benefits from such a policy, there are many concerns that have been raised regarding not only the challenges to implementation, but also their potential effect on the livelihoods of forest-dependent communities (Angelsen 2008; Fry 2008; Humphreys 2008, Rights and Resources Initiative 2008).

In Cameroon, as in many African countries, the state is the sole guardian and chief manager of all forests in the country and has the exclusive right to exclude and allocate rights to economically exploit forest resources to the local population and corporate companies (Van den Berg and Biesbrouck 2000). Although most forest people gain access to the forest through customary systems of tenure, customary land rights are not legally recognized as ownership rights but as user rights (Diaw 1997; Van den Berg and Biesbrouck 2000; Cotula and Mayers 2009). Community forestry was introduced with the Forestry Act of 1994, but devolved rights are limited to management under supervision of the government (Vabi et al. 2000; Oyono 2004b, a; Cotula and Mayers 2009). The complexity of managing such an important socialecological system underscores the importance of searching for ways to enhance the capacity of the system to respond to the challenge. In social-ecological systems, the existence of institutions and networks that learn and store knowledge and experience, create flexibility in problem solving and balance power among interest groups, play an important role in enhancing adaptive capacity (Tompkins and Adger 2004; Walker et al. 2006; Pahl-Wostl 2009). In climate change research, the institutions of the state, the market, and civil organizations have been found to play an important role in determining response to changing environmental and policy conditions and risks (Adger 2000; Adger and Vincent 2005; Smit and Wandel 2006). Studies have shown that a significant factor influencing the climate policies that are adopted is the way in which decision-makers perceive climate change (Pielke 1998; Koch et al. 2007). Given the important role that the Congo Basin forest plays in the economy and livelihoods of the people of Cameroon, it is important to understand the perspectives and response of important stakeholders with respect to the opportunities and challenges of climate change.

The aim of this research is to analyse the perceptions of decision-makers within, and the response of the institutions of the state, the private sector and civil society to the complex challenges of climate change in Cameroon. First the literature on vulnerability and adaptation to climate change is reviewed and the important role of institutions in enhancing climate change response is discussed. The research methods are then described and interview results of how different representatives of the various institutions perceive climate change and its impact on Cameroon are presented. Additionally, the current strategic priorities of the different institutions to address climate change are outlined as well as respondents' perception of the constraints on Cameroon's capacity to respond. A multi-level governance framework is used to analyse the networks occurring between different institutions, as well as other important stakeholders. The paper concludes with a discussion of the results and suggests opportunities for building adaptive capacity to climate change in Cameroon.

\section{Vulnerability and adaptation}

Within the climate change literature, the vulnerability of any system (at any scale) is reflective of (or a function of) the exposure and sensitivity of that system to hazardous 
conditions and the ability or capacity or resilience of the system to cope, adapt or recover from the effect of those conditions (Smit and Pilifosova 2003; Adger 2006; Smit and Wandel 2006). Adaptive capacity refers to the potential or capability of a system (whether environmental, social or economic) to cope with not only climate risks but also climate opportunities (Adger 2003b; Keskitalo 2004). It is similar to other commonly used concepts such as adaptability, coping ability, management capacity, stability, robustness, flexibility and resilience (Smit and Wandel 2006). Adaptive capacity is a function of the asset base from which adaptation actions and investments can be made (Adger and Vincent 2005). Some determinants of adaptive capacity are mainly local while others reflect more general socio-economic and political systems. They include economic wealth, technology, information and skills, infrastructure, institutions, social capital and equity (Smit and Pilifosova 2001, 2003). These determinants are closely interconnected and important to consider when examining strategies to enhance the capacity of a system to adapt to climate change.

Institutions have long been identified as a key part of governing human interaction with a changing environment. Broadly defined, institutions are the prescriptions that humans use to organize all forms of repetitive and structured interactions (Ostrom 2005). O'Riordan and Jordan (1999) state that institutions apply both to structures of power and relationships as found in organizations with leaders, membership, resources and knowledge, and socialized ways of looking at the world as shaped by communication, culturally ascribed values, and patterns of status and association. Institutions for monitoring and responding to environmental and social changes determine the tightness of feedbacks among social and ecological components and ultimately affect their adaptability (Walker et al. 2006). Additionally, interactions between local and higher level institutions affect the capacity of a community to respond to change (Adger et al. 2005; Smit and Wandel 2006; Agrawal 2008). According to Adger (2000), the institutions of the state, market, and civil organizations are major determinants of collective security, social vulnerability, and environment and resource allocation.

In social-ecological systems, the existence of institutions and networks that learn and store knowledge and experience, create flexibility in problem solving and balance power among interest groups, play an important role in adaptive capacity (Tompkins and Adger 2004; Walker et al. 2006; Pahl-Wostl 2009). Furthermore, strong networks among diverse institutions across scales enhance the adaptive capacity of the system to respond to the challenges of changing circumstances. However, weak links among institutions that fail to plan for changing environmental and policy conditions and risks, constrain adaptive capacity and increase vulnerability (Adger and Vincent 2005). Adaptive capacity is reflected in the adaptations or changes in a system to better deal with problematic exposures and sensitivities (Smit and Wandel 2006). Given the diversity of impacts of climate change, it is a problem that demands concerted collective action involving a multilevel response from many institutions and other actors (Adger 2003a; Thynne 2008).

\section{Methods}

This research was carried out in the Republic of Cameroon, a country in central Africa covered by the Congo Basin Forest in the south, which is an important part of its economy and source of livelihood for the local population (Fig. 1). While there are many formal and informal institutions at different levels that could potentially have been included in this study, for the purposes of this research we focused on formal national, regional and 


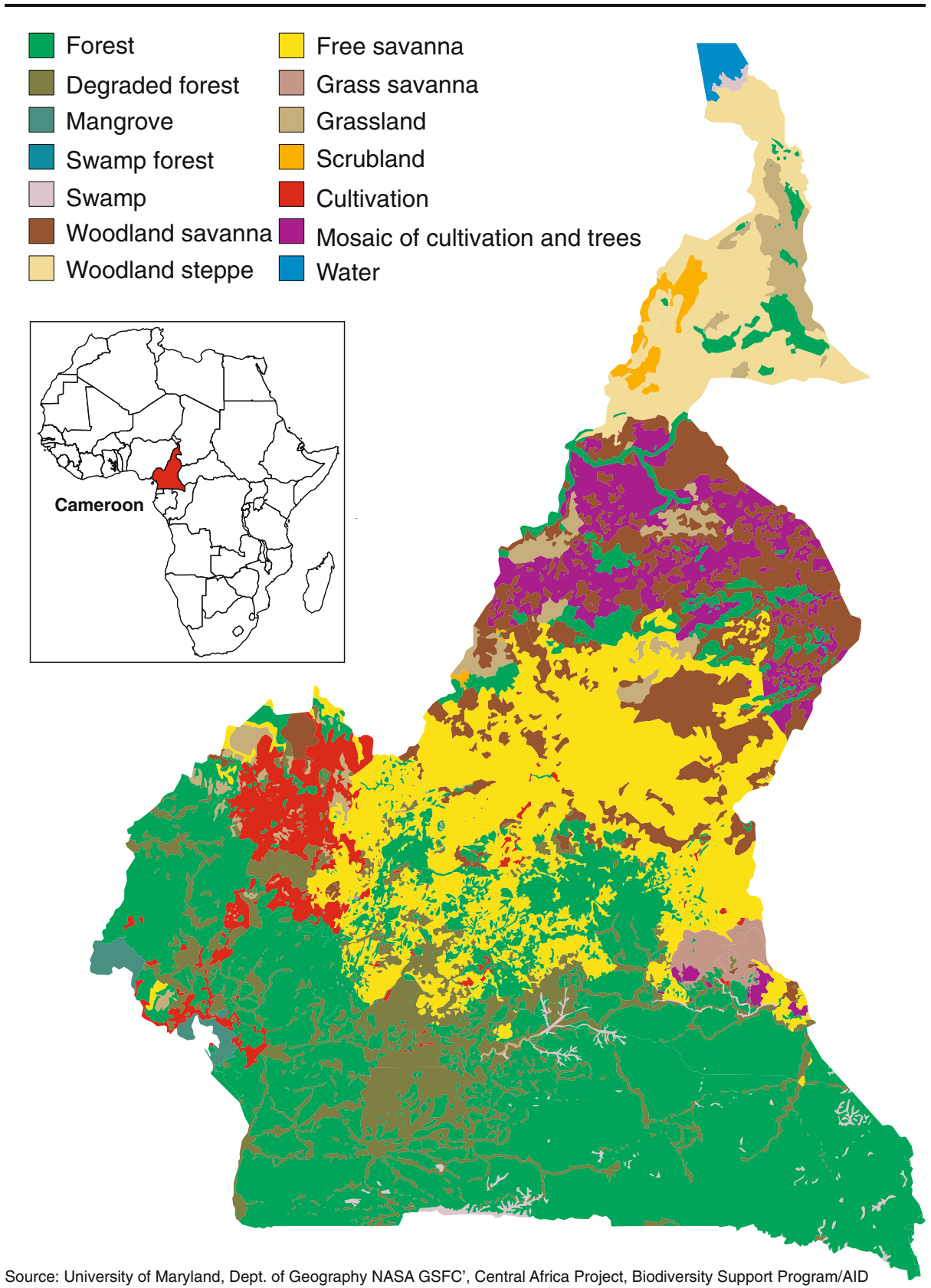
http://www.geog.umd.edu/carpe/gisthemes.html

Fig. 1 Map of vegetation of Cameroon showing forest areas

international institutions because of their decision-making role in climate change or forest issues or because of the impact climate change might have on them in the future (Table 1). The selected institutions represented various government ministries, parastatal, regional and international institutions, the private sector and civil society. Within the private sector, data 
Table 1 Summary of participating institutions

\begin{tabular}{|c|c|c|c|c|c|}
\hline Government & Parastatal & NGO & Private Sector & International Organization & Regional \\
\hline MINFOF & \multirow[t]{8}{*}{ ANAFOR } & IUCN & FIPCAM & World Bank & \multirow[t]{8}{*}{ COMIFAC } \\
\hline MINEP & & WWF & Pallisco & UNDP & \\
\hline MINRESI & & WCS & SFID & Coopération Française & \\
\hline MINADER & & $\mathrm{RACC}$ & TRC & & \\
\hline \multirow[t]{4}{*}{ IRAD } & & Living Earth & WIJMA & & \\
\hline & & CARPE & ALPICAM & & \\
\hline & & CED & & & \\
\hline & & CERAD & & & \\
\hline
\end{tabular}

Full meaning of acronyms

MINFOF Ministry of Forests and Wildlife, MINEP Ministry of the Environment and Nature Protection, MINRESI Ministry of Scientific Research and Innovation, MINADER Ministry of Agriculture and Rural Development, IRAD Agricultural Research and Development Institute, ANAFOR National Agency for Forest Development, IUCN The World Conservation Union, WWF The World Wide Fund for Nature, WCS Wildlife Conservation Society, RACC African Network for a Climate Community, Living Earth The Living Earth Foundation Cameroon Programme, CARPE Central African Regional Program for the Environment, $C E D$ Centre for Environment and Development, CERAD Centre for Action Research for Sustainable Development in Central Africa, SFID Société Forestière et Industrielle Doumé, UNDP United Nations Development Program, COMIFAC Central African Forest Commission

was collected from representatives of six national and international forestry companies who have obtained or are in the process of obtaining certification as practitioners of sustainable forest management by third party review. While it is recognized that the views of these forestry companies may differ from those that are not involved in certification processes, it was not possible to obtain interviews with representatives of others. Within civil society, respondents from eight national and international non-governmental organizations (NGOs) operating in Cameroon were interviewed. One regional organization, the Central African Forest Commission (COMIFAC), was also included. Additionally, data was collected from three international organizations.

The representatives of the institutions were chosen for interviews because of their decisionmaking role or involvement in the climate change debate. Where there was no active institutional participation on climate change issues, the positions of those chosen exposed them to the issues in general terms. In most cases, one respondent from each institution was interviewed, except for the Ministry of Forests and Wildlife, which had two respondents. Twenty-seven semi-structured, open-ended interviews were conducted in September and October 2008. Use of this qualitative approach in data collection, allows the interviewer to use a guide to explore similar questions with all the institutional representatives, with the flexibility necessary to ask further questions in order to elucidate the subject (Patton 2002). See Table 2 for the general interview guide. Interviews were conducted in French or English, depending on the preference of the person being interviewed and were digitally recorded for later transcription. Direct quotations from French have been translated into English. Interview data was supplemented by a review of relevant documents, strategies, press releases and government statements related to the key themes.

Content analysis of the data was done in order to identify, code and categorize the patterns in the data following key themes as outlined in the interview guide (Patton 2002). Key themes explored during the interviews were the effects of climate change on the population of Cameroon and in particular the Congo Basin Forest area. Additionally, the 
Table 2 Types of questions that were explored during interviews with representatives of government, the private sector and civil society

Sample Interview Guide

Could you explain to me the mandate of your government department, NGO or the type of business that your company does? Please specify the types of activities that you do.

Are any of your activities related to climate change mitigation or adaptation? Please specify the types of activities that you are doing.

What are the opportunities and constraints in carrying out your work? Either in the climate change area or in general?

What will be the impact of climate change on the people of Cameroon?

Are you aware of international policies related to climate change?

What measures will enhance the adaptive capacity of Cameroon to respond to climate change?

What is your primary way of communicating or relating to others in government or other organizations or local people? on the issue of climate change?

perceptions of international climate change policy were noted. Institutional strategic priorities related to climate change and perceptions of Cameroon's capacity to adapt were also explored. Opportunities and constraints in implementing activities were highlighted. A multi-level governance framework was used to analyse the relationships occurring among different institutions and with other important stakeholders (Keskitalo 2004; Koch et al. 2007). Linkages were classified as non-existent, weak (little contact), moderate (occasional contact) and strong (ongoing regular contact).

\section{Results}

\subsection{Perceptions of impact of climate change}

All interviewees were aware of the issue of climate change, and there was broad consensus that the poor would be most affected. They felt this would be a result of changes that would affect agriculture and forests which are the key sources of livelihood. Additionally, it was felt that if there were any climate events, such as floods, the poor would also be the most affected. As one government official said, "It is the poor people and the people with economic problems like ours, who will undoubtedly be hurt the most."

While acknowledging the direct effects of climate change, respondents felt that any changes in the forests would happen in the long term. They stated that climate change would have an effect on biodiversity in the forest zone, which could lead to changes in the range of some species of plants and animals and possibly their ultimate disappearance. This in turn would have a negative effect on local communities who depend on the forest for their livelihood. They felt that these changes in the forest would affect indigenous huntergather populations differently than agriculturalists. One NGO commented,

"The primary impact is of course on the biodiversity. You know that with climate change there will be many changes in habitat. That means that what the local population eats will change. ... Therefore, if there is an impact on what people are eating, there is automatically a negative impact on the well-being of communities."

Respondents also suggested that an indirect effect of climate change on the forest could result from increased migration from the north to the southern part of the country, which 
would place pressure on forest resources. The northern part of Cameroon is part of the Sudano-Sahelian zone, and respondents suggested that climate change would be more prominent in the short term in this region leading to increasing variability in the timing and amount of rainfall.

Many respondents expressed concern that changes, possibly due to climatic change, were already being observed in terms of variation in the arrival of rains which affect the agricultural calendar and forestry operations. The concern was expressed that the timing of wet and dry seasons was not as distinct as in the past and that this was having an impact on agricultural production in the short term. Several representatives of forestry companies felt that the unpredictability of the rains as well as the quantity of rain was beginning to affect their business operations. As they are unable to harvest timber during the rainy season these changes result in a disruption in their harvest plans.

Other respondents stated that changes were already evident outside of the forest zone, particularly in the northern part of the country as the desert was advancing. Additionally, one NGO stated that in the coastal areas, elderly people told stories of how the sea level has changed over their lifetime. However, one government official stated that although some changes were being observed, it was not necessarily a result of climate change as there were other occurrences of environmental degradation that could lead to increased flooding, for example. One NGO also felt that changes due to logging and mining were currently occurring that were not due to climate change, and were having a negative effect on the biodiversity of the forests as well as on livelihoods of local people.

\subsection{Perceptions of climate change and international policy}

The general perception among government institutions was that the developed countries should bear the weight of the responsibility for climate change and should be ready to compensate developing countries financially for any efforts in climate change mitigation. Some representatives were very firm in their statements concerning the fact that climate change is the responsibility of developed nations, not Africa. Other government representatives expressed concern that Cameroon be able to have a real voice in current international negotiations which they perceived was not always the case. One stated, “...the risk is that it will all be negotiated without us, without our country being admitted...there are many things that are negotiated, and they are presented to us as a done-deal that we must implement." In particular, concern was expressed about the implications of the international negotiations surrounding REDD for the people of Cameroon. There was an acknowledged need for this international policy to take into account the concerns of the poor.

NGOs expressed concern that REDD could have far reaching implications for indigenous and forest-dependent communities whose access to the forest could be restricted to ensure forest conservation. One NGO suggested that the possibility of revenue via REDD was seen by government officials as a "cash cow". He expressed concern that, in a manner similar to other international initiatives, such as with HIV/AIDS, there would be little accountability and that the end result would not benefit the people of Cameroon or the global climate.

\subsection{Current strategic priorities to address climate change}

\subsubsection{Government}

While climate change is just coming to the fore as a priority in most institutions interviewed, the national government of Cameroon ratified the Kyoto Protocol in 2002. In 
accordance with the Kyoto Protocol, a designated authority for the Clean Development Mechanism (CDM) was created to foster the development of such projects in Cameroon. Some international donor-supported workshops have been held to disseminate information and some CDM projects have been developed, but at the time of writing no projects had reached the stage of final approval (UNFCCC 2009). A national office was also created in the Ministry of Environment and Nature Protection (MINEP) as the national focal point to the United Nations Framework Convention on Climate Change (UNFCCC). Most recently, the President of the Republic announced that a national observatory will be built which will provide ongoing monitoring of climate data. The national observatory will have two roles, first as a tool to help facilitate decision making in all sectors on climate change, and second to be a permanent monitor of the carbon stock of Cameroon.

While the Climate Change desk in MINEP appeared to be under staffed and lacking in resources, it has accomplished some important tasks. In 2004 they developed the first national communication on climate change which provided an inventory of the greenhouse gas emissions in Cameroon, based on its geography and all sectors of the economy. At the time of the research, they were in the process of developing the second national communication on climate change. Additionally, an assessment of the vulnerability of Cameroon to future climate change was done with international support, and the coastal zone and the Sudano-Sahelian zone were identified as being particularly vulnerable. Cameroon has joined other Congo Basin countries to contribute to the international negotiations on post-Kyoto, particularly aspects related to REDD. In fall 2008, Cameroon presented its Readiness Planning Idea Note (R-PIN) to the World Bank and was accepted as one of 30 developing countries to the Forest Carbon Partnership Facility (The World Bank 2008b). As Cameroon is not a designated Least Developed Country, it was not required to develop a National Adaptation Program of Action (UNFCCC 2010).

The Ministry of Forests and Wildlife (MINFOF) and its associated parastatal, the National Agency for Forest Development (ANAFOR), responsible for reforestation efforts in the country, felt that the tree planting projects they were embarking on, particularly in northern Cameroon, were a key part of responding to climate change. Some reforestation projects were also currently under development as CDM projects. Additionally, MINFOF was closely following the international negotiations around REDD and its implications for the Congo Basin forest. IRAD has also been involved in some past research on carbon dynamics and land use in the humid forest zone (Kotto-Same et al. 1997). Government officials said that it was now time for Cameroon's policy on climate change to be integrated into all aspects of government.

However, the result of all government interviews and review of documents seemed to indicate that there was little concrete integrated action on climate change. Any action that was being carried out was clearly at a very early stage. Other government departments, while being aware of the issue had not begun any work in that area. Many NGOs interviewed felt that, while there had been some announcements at the national level, the issue of climate change had not yet become a priority for the government of Cameroon. They felt that parliamentarians who were elected for terms of only five years, were not interested in an issue which they feel will have no consequences for several decades or for their re-election.

\subsubsection{Non-governmental and International Organizations}

Some NGOs interviewed have already made climate change a priority for their work in Cameroon. For example, The World Conservation Union (IUCN) has climate change as a 
strategic priority for their plan of work from 2009-2012 with a focus on building knowledge around the issue and investigating alternative sources of energy that will have less of an impact on the global climate. Additionally, it works with the Central African Forest Commission (COMIFAC), a regional body which draws together political officials and civil society to harmonize environmental policy, with the objective of promoting the conservation and sustainable management of the Congo Basin forest ecosystem.

The regional organization of the Central Africa Forest Commission (COMIFAC) has been playing a key role in capacity building and coordinating a response to REDD across the countries of the ecoregion (Commission des Forêts d'Afrique Centrale (COMIFAC) 2009a). They have held regional workshops on REDD in order to consolidate a coordinated program in preparation for future negotiations under the UNFCCC (Commission des Forêts d'Afrique Centrale (COMIFAC) 2009a). They were implicated in the REDD process together with the World Wide Fund for Nature (WWF) and MINEP in preparing the R-PIN for submission to The World Bank (Ministry of the Environment and Nature Protection (MINEP) of the Republic of Cameroon 2008). Additionally, a study of the sustainability of an observatory for monitoring the condition of the forests of central Africa has been undertaken (Commission des Forêts d'Afrique Centrale (COMIFAC) 2009c). They also submitted a proposal on the implementation of REDD to the Subsidiary Body on Scientific and Technical Advice (SBSTA) of the UNFCCC (Commission des Forêts d'Afrique Centrale (COMIFAC) 2009b; Parker et al. 2009).

Most NGOs felt that the work that they were already doing with forest-dependent communities related to sustainable development, while not explicitly about climate change, was laying a solid foundation for helping local people to adapt to climate change. Another NGO stated that they were actively integrating climate change into their program, as there was a lot of international money available for climate change that could also be used to benefit other aspects of their work. One local NGO was actively involved in regional initiatives on climate change and was in the process of investigating projects that would be part of the voluntary carbon market.

International organizations are heavily involved in working with government institutions on climate change issues. The United Nations Development Program (UNDP) has been actively building government capacity on the issues, particularly at MINEP, and facilitated the attendance of government officials at international meetings on climate change. La Coopération Française, which has an advisory role in the offices of MINFOF and MINEP, has been most involved in workshops about the CDM and in initiating reforestation projects in some parts of Cameroon, which potentially could come under the CDM. The World Bank has facilitated the preparation of Cameroon's R-PIN for submission to the Carbon Forest Partnership Fund.

\subsubsection{Private sector}

While some respondents from the forestry companies noted that changes in climate might be affecting their harvesting operations, they did not see climate change as an immediate priority in the overall operations of their companies. However they were aware that it might play a larger role in the future, particularly as a result of international policies such as REDD, the CDM and the voluntary carbon market. The companies interviewed had been certified, or were in the process of becoming certified, as practitioners of sustainable forest management, which they said was a result of pressure from their European customers. Therefore, they felt similar pressure regarding climate change would result in it becoming 
more of a priority for their companies in the future. Some companies had attended a CASCADE workshop held by la Coopération Française which seeks to enhance African expertise to generate carbon credits (United Nations Environment Program (UNEP) 2008). Several companies felt that as a result of their reforestation practices they were contributing to increasing the carbon sequestration potential of the forests. Others said that they were studying the possibility of co-generation of electricity as a way to reduce their costs and limit greenhouse gas emissions.

\subsection{Capacity to adapt to climate change}

Most institutions felt that a key challenge to Cameroon's capacity to adapt to climate change was a lack of infrastructure and financial and human capacity. At the national level these constraints were seen as being particularly acute in government and research institutions where there is a serious lack of capacity on the technical aspects of climate change. While government officials had attended some capacity-building seminars on climate change, the general feeling was that these constraints on capacity would be a serious problem for Cameroon in the post-Kyoto period. One official stated,

"We are entering into a period to prepare the post-Kyoto period. We need to have capacity in terms of information. In terms of monitoring, the quality of forests and others, in terms of receiving and analysing satellite images, in terms of understanding these new tools, such as the carbon market and others, all these require capacity. But, unfortunately, it's necessary to state that here it is not sufficient. ... we have a big problem of capacity.

While there are constraints on the government's capacity to respond to climate change, some institutions felt that Cameroon, as a country which contains part of the Congo Basin forest has an opportunity to influence future international climate change negotiations. However, many institutions also felt that African countries, in general, are at a disadvantage as they have less knowledge of the international negotiation process than northern countries. The Bangui Declaration of the COMIFAC countries also cites a linguistic barrier for central African negotiators (Commission des Forêts D'Afrique Centrale (COMIFAC) 2008). To that end, NGOs and other international organizations are involved in building the capacity of Congo Basin Forest countries concerning the implications of forest policies, such as REDD.

A lack of awareness among the general population of the issue of climate change and its implications was identified by respondents. However, they felt that this was not surprising as it is something that has only recently come to the fore in national discussions. In addition to this knowledge gap, NGOs stated that the population in general is very poor and so have little capacity to respond to extreme climate events, or to formulate positions on international climate policies, such as REDD, which may affect their livelihood. Some NGOs felt that while building a climate observatory was useful, it would be much better for the government to build the capacity of the population to adapt to climate change. Some felt that linking climate change and economic concerns would help the population to better understand its importance. Government institutions felt that a lack of awareness of climate change at the community level was also constraining any reforestation programs that they were trying to implement. Additionally, they are constrained by lack of a clear definition of land tenure.

\subsection{Institutional networks}

Inter-departmental government activity on the issue of climate appeared to be limited, although there was some indication that inter-departmental discussions were occasionally 
taking place (Fig. 2). For example, the Director of MINFOF responsible for forests said he had recently started to have regular conversations about climate change with the Climate Change desk in MINEP, particularly since the role of forests had become more prominent in international negotiations. Additionally, with the announcement of an observatory for Cameroon, the Ministry of Scientific Research and Innovation (MINRESI) and its research offices felt that this would increase their interaction with MINEP on climate change research. Other departments, such as the Ministry of Agriculture and Rural Development (MINADER), felt that since they normally needed to communicate with MINEP during the course of their work, that this would logically continue as the issue of climate change becomes more prominent. One government representative said that they had already participated in some seminars on the issue of climate change. ANAFOR already works under MINFOF and some of its work was directly related to climate change mitigation. It is important to note that while interview results indicate that there may be some institutional links at the national scale on climate change, there was no indication of any linkages with lower levels of government or communities.

Some NGOs, felt that government departments were beginning to communicate on the issue of climate change. However, based on their experience, other NGOs felt that climate change was not being integrated into the work of government departments. In particular, they felt that at the present time there was no link between government institutions responsible for biodiversity conservation and those responsible for climate change. One representative commented on a meeting he had attended to discuss biodiversity conservation, "...Ministry of Forests, Ministry of Environment, all the donors, community, working on the programme, to see how the programme is going. It took four, five hours, but nobody talks about climate change! "

Additionally, other NGOs commented that government departments had limited collaboration in their work, in general. As evidence they cited the granting of mining exploration permits in protected areas and land already designated for other uses such as logging concessions. The overlap of logging concessions with mining explorations was

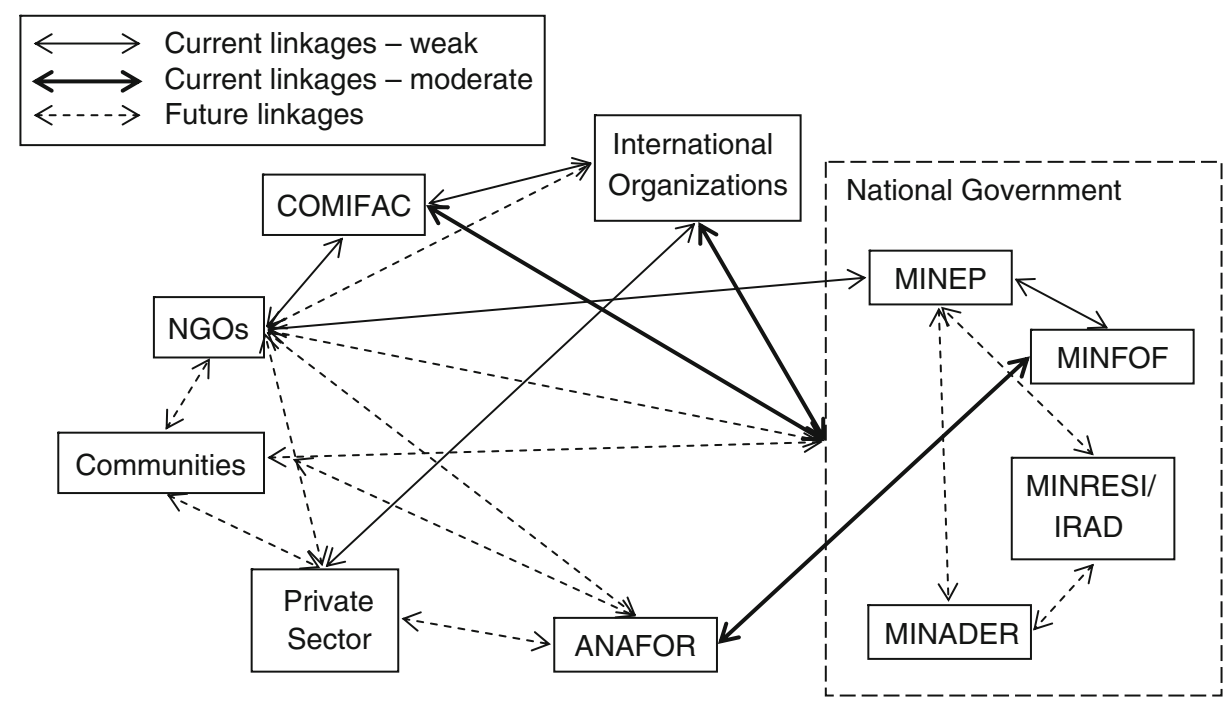

Fig. 2 Current and future inter-institutional linkages on climate change in Cameroon 
cited as a problem by several forestry companies as well. This situation reveals a weak coordination among government departments.

Questions were also posed to elucidate the linkages between government institutions and NGOs. Some of the larger international NGOs, such as IUCN, Wildlife Conservation Society (WCS) or the World Wide Fund for Nature (WWF), work closely with government, in some cases to strengthen capacity in the area of biodiversity conservation and more recently in the area of climate change. Some NGOs felt that they had more contact with government institutions than the government institutions did with each other. One national NGO, which works primarily with indigenous people, said that they were in communication with the Ministry of Social Affairs but that this was not on the issue of climate change. Additionally, links with COMIFAC appeared to be quite well developed as regional representatives of government were beginning to focus on climate change, particularly the implications of REDD.

In reality, most national NGOs felt that they had few links with government in any area and were not currently part of any discussion on issues of climate change. One NGO representative said that they learned information about the government's action on climate change the same as any other citizen would - from the local media. Other NGOs cited the workshop held by the Congo Basin Forests and Climate Change Adaptation program (CoFCCA), of the Center for International Forestry Research, in 2008 as the first opportunity to have discussions on climate change. Not surprisingly, in contrast, the international organizations of the World Bank, the United Nations Development Program (UNDP) and la Coopération Française worked closely with the government on the issue of climate change. In particular, la Coopération Française functions as a technical advisor to both MINEP and MINFOF.

While links with government were nonexistent on climate change, the forestry companies work closely with MINFOF which monitors their forest exploitation and reforestation. Some have linked with NGOs on climate change through attendance at a CASCADE workshop held by la Coopération Française (United Nations Environment Program (UNEP) 2008). Additionally, one company said that they were involved through la Coopération Française with a reforestation project that is in the CDM application process. Some national NGOs were also part of such workshops. The forestry companies have worked closely with WWF in the process of becoming certified as practitioners of sustainable forest management and are part of the Central African Trade Network. Generally, the forestry companies link with local NGOs in the process of their work in communities.

Another important linkage to consider is that of various institutions with local communities. Since there appeared to be no linkages concerning climate change between national and lower level of governments, it is not surprising that there appeared to be no government action at the community level on climate change. The only possible regular linkage related to climate change appeared to be the tree planting work that ANAFOR carries out in conjunction with local communities. Actors in civil society, international and national NGOs both have close linkages with communities in carrying out their work. The private forestry companies also work in communities by carrying out social service initiatives such as building health clinics.

\section{Discussion}

\subsection{Perceptions and priorities}

The fact that there is general awareness among the various institutional representatives interviewed of the problem of climate change is an opportunity for formulating a 
response. Since many said that they are already noticing some changes that may be explained by global climate change, this may influence decisions that are made in their respective institutions related to climate change. It is also important that many stated that the poor would be most affected by any environmental or policy change. However, how any of these perceptions would be translated into policy was not evident. While representatives of government and civil society institutions stated that climate change was a priority, any concrete response was clearly at an early stage for all institutions in Cameroon, as it is in many countries globally (Orindi and Murray 2005; Intergovernmental Panel on Climate Change (IPCC) 2007a; Koch et al. 2007). This may be a result of other pressing development issues of poverty reduction, sustainable development, education and economic growth or fiscal constraints. Adger et al. (2003) conclude that in an African context, most countries' priorities relate to poverty reduction and development and not to the risk of long-term climate change, although such issues cannot be divorced from one another.

At the time of the research, the only government institution, which was formulating a response to climate change, was the UNFCCC focal point in MINEP. Likely due to its limited resources, its action has been confined to the development of statements and policies at the national level. Other government institutions were not fully aware of what their roles should be in terms of climate change. While the parastatal, ANAFOR, was continuing to carry out its reforestation mandate, its action addresses only a specific aspect of climate change. Given the importance of the Congo Basin forest in biodiversity conservation, the economy, and the livelihoods of millions of local people, other parts of MINEP, as well as other government departments should have had climate change as a greater priority. Additionally, MINFOF and ANAFOR should have begun to implement recommended forest management practices that would enhance adaptation to the direct effects of climate change (Smith and Lenhart 1996; Robledo and Forner 2005; Seppälä et al. 2009). Institutional weakness has been identified in other studies as a source of forest mismanagement in Cameroon (Oyono 2005; Mbatu 2009).

However, the recent emphasis on the role of the Congo Basin Forests in mitigation of climate change through such policies as REDD is playing a role in building awareness of climate change for those institutions interviewed. This was particularly true for government and civil society institutions as they are interested in the opportunities presented by REDD, and also concerned about its challenges in terms of implementation. However, any action to take advantage of these opportunities or address apparent challenges is still at an early stage. This is not surprising given that discussions on how REDD should be implemented are still taking place at the international level. However, the global significance of the Congo Basin forest will likely continue to dominate the discourse on climate change in Cameroon in the near future.

The forestry companies were not as aware of the details of climate change policy discussions on forests but were aware that such policies might present opportunities for them to enhance their business. Since the companies interviewed were certified, or in the process of becoming certified as practitioners of sustainable forest management, they are already aware how international pressure on environmental issues can influence their business practices. Therefore, they could be expected to pursue opportunities from international climate change policies on mitigation or adaptation that will also make good business sense in the future. However, not all forestry companies are aware of such opportunities or choose to seek to leverage such benefits from sustainable forest management. 


\subsection{Enhancing adaptive capacity}

Similarly to other parts of Africa, Cameroon is considered to have a high level of social vulnerability to the direct effects of climate change due to many factors, such as level of poverty and the level of corruption (Adger and Vincent 2005; Intergovernmental Panel on Climate Change (IPCC) 2007b). Therefore, it is not surprising that government officials and civil society organizations identified that the key constraint in responding to climate change was a lack of infrastructure and human, technical and financial capacity. According to Smit and Pilifosova (2003) the lack of key determinants of adaptive capacity, such as economic wealth, technology, information, skills and infrastructure, increase the vulnerability of nations and communities to the various challenges of climate change. Lack of these key determinants limits Cameroon's ability to reduce vulnerability and take advantage of opportunities.

In Cameroon challenges come, not only from potential bio-physical changes in its diverse landscape but also from the unknown implications of policies, such as REDD. Despite international discussions of the opportunities presented by various carbon trading systems, questions remain as to whether they can be effective solutions to multiple challenges when implemented in countries, such as Cameroon, with weak governance systems and monitoring mechanisms. Some feel that the scaling up of emissions trading is more of a reflection of the interests of rich countries as opposed to those of poorer countries (Gupta 2008). Concern has been raised globally about the impact of such policies on indigenous and other forest-dependent communities (Rights and Resources Initiative 2008; Streck et al. 2008; Cotula and Mayers 2009). Therefore, it is essential that Cameroon increase its capacity in all areas, particularly human and technical capacity, to respond. This will necessarily involve engagement with forest-dependent communities on the issue.

Some progress has been made, with international support, such as that from the UNDP and La Coopération Française, which have addressed a lack of capacity in some areas in government, the private sector and civil society institutions. Furthermore, international organizations, COMIFAC and NGOs have facilitated the preparation of the R-PIN so that Cameroon will have the support of the Forest Carbon Partnership Facility in preparing for REDD. However, while awareness has been raised in the various government institutions and NGOs, and a climate observatory has been promised, huge gaps in information, skills and technology remain. This is particularly evident in the limited resources of the MINEP focal point to address climate change issues. There are also concerns as to whether or not Cameroon has the capacity to have an effective voice in future negotiations on climate change. A concern for an effective African voice in climate change negotiations has been echoed by other African countries (African Forest Forum 2009).

As identified earlier, the existence of institutions and strong networks that learn and store knowledge and experience, and plan for changing environmental and policy conditions and risks enhance adaptive capacity (Tompkins and Adger 2004). Good inter-sectoral coordination is also important since policies in other sectors such as agriculture, transportation and resource development will have significant impacts on forests (Seppälä et al. 2009). Furthermore, the recent integration of diverse actors in global forest governance has enhanced sustainable forest management (Visseren-Hamakers and Glasbergen 2007; Agrawal et al. 2008). Therefore, it is of concern that results show that overall current institutional linkages within government at the national level are weak, in particular on the issue of climate change. Such weak institutional linkages on climate change have also been noted in other African countries (Orindi and Murray 2005; Koch et al. 2007). The apparent lack of links with different levels of government and local 
communities in Cameroon regarding climate change constrains adaptive capacity and could increase the vulnerability of local populations (Smit and Wandel 2006). However, the moderate linkages of international organizations and international NGOs with MINEP are playing an important role in enhancing the capacity of Cameroon to respond. Additionally, the regional connection of Congo Basin countries through COMIFAC provides a network for sharing of resources and knowledge to coordinate a response to new policies like REDD. Other networks such as the African Forest Forum also have a role to play in capacity building (African Forest Forum 2009).

It has been shown that well-connected networks enhance communication, favour collaboration, build social capital and foster innovation which is essential in dealing with an issue such as climate change (Carlsson and Sandstrom 2008). Therefore, it is essential that networks of stakeholders in government, civil society and the private sector be strengthened in order to increase Cameroon's overall adaptive capacity. However, it is also critical that government institutions engage with the local population whose livelihoods are most at risk from changing environmental and policy conditions. Such engagement will increase adaptive capacity as it will provide opportunity for sharing of knowledge and concerns and build social capital (Tompkins and Adger 2004; Walker et al. 2006; Pahl-Wostl 2009). Government respondents felt that this may be most effectively done through international and national NGOs who already have close relations in working with communities. NGOs already play a key role in linking with communities in decentralized forest management in Cameroon (Brown et al. 2008b).

However, since the complexity of the climate change problem requires a coordinated, multilevel response from many institutions and other actors it is important to design appropriate institutions that can facilitate such linkages. In tackling such 'wicked problems' Weber and Khademian (2008) identify that a collaborative capacity builder, from either inside or outside government, is often helpful in fostering the transfer, receipt and integration of knowledge across the networks and ultimately building long-term collaborative problem-solving capacity. While the UNFCCC focal point in MINEP has potential to play such a role, it is severely limited by a lack of resources. Therefore, while Cameroon's institutional capacity needs to be reinforced in many areas, building human and technical capacity in this office may be one way to enhance the country's overall adaptive capacity. However, a collaborative capacity-builder could also be located within civil society.

The weak networks among institutions, in general, and on climate change in particular, has serious implications for the effectiveness of national response to climate change and to new international policies on forests. Therefore, networks need to be strengthened at the level of policy making, as well as at the level of implementation of adaptation strategies. While constraints on capacity need to be overcome, according to one government official "there are still some institutional arrangements that need to be put into place in order to adequately respond to climate change." The development of institutional arrangements could be facilitated by the presence of a collaborative capacity builder, that could strengthen networks so that the transfer and receipt of knowledge could be fostered and ultimately build long-term collaborative problem-solving capacity.

\section{Conclusion}

Climate change presents many challenges to a country such as Cameroon which has a diversity of landscapes and shares the second largest tropical rainforest in the world, the 
Congo Basin. Not only is the population vulnerable to the direct effects of climate change, forest-dependent communities are also vulnerable to any environmental policy changes that may affect their access to forest resources which are a source of their livelihood. The complexity of the issues requires that there be a committed, integrated effort that cuts across state-private sector-civil society boundaries.

Results showed that while there was general awareness of the climate change issue among decision-makers, institutional response was at a very early stage. Although many within institutions felt that climate change was occurring in Cameroon, this perception did not seem to spur any concrete institutional action. However, the international discussions surrounding the importance of forests in climate change appeared to be fostering increased awareness and action in some areas at the national level. Action must be taken, therefore, to build adaptive capacity through communicating climate change information more broadly and effectively, and building awareness of its potential impacts and strategies to adapt at all levels. Furthermore, human and technical capacity needs to be enhanced on all aspects of the implementation of the carbon market and its implications for the forest. While there have been some interactions between some civil society organizations and the government in formulating Cameroon's position on policies such as REDD, overall many institutional networks appear to be weak. Weak linkages were especially evident among government institutions and between different levels of government and with local forest communities which is likely to reduce national adaptive capacity to climate change. While NGOs and forestry companies dealt with communities on some issues related to forests, biodiversity conservation and sustainable development, there are no links related to climate change.

The weak networks among institutions, in general, and on climate change in particular, has serious implications for the effectiveness of national response to climate change and to new international policies on forests. Therefore, networks need to be strengthened at the level of policy making, as well as at the level of implementation of adaptation strategies. In particular, concerted efforts need to be made to involve local communities in the climate change dialogue. The development of institutional arrangements could be facilitated by the presence of a collaborative capacity builder, that could strengthen networks so that the transfer and receipt of knowledge could be fostered and ultimately build long-term collaborative problem-solving capacity.

Acknowledgements We would like to thank all the institutions for giving time from their busy schedules for the interviews. This research was conducted under the International Development Research Centre (IDRC) funded Congo Basin Forest Climate Change Adaptation project of the Center for International Forestry Research, a Social Sciences and Humanities Research Council of Canada Postdoctoral Fellowship and the Global Environmental Change Group at the University of Guelph. We would also like to thank Dr. Barry Smit for his helpful comments on an earlier version of this manuscript. We thank the three reviewers whose comments have substantially improved the paper.

\section{References}

Adger WN (2000) Institutional adaptation to environmental risk under the transition in Vietnam. Ann Assoc Am Geogr 90:738-758

Adger WN (2003a) Social aspects of adaptive capacity. In: Smith J, Klein RJT, Huq S (eds) Climate change, adaptive capacity and development. Imperial College Press, London, pp 29-49

Adger WN (2003b) Social capital, collective action, and adaptation to climate change. Econ Geogr 79:387404

Adger WN (2006) Vulnerability. Glob Environ Change 16:268-281 
Adger WN, Vincent K (2005) Uncertainty in adaptive capacity. CR Geoscience 337:399-410

Adger WN, Huq S, Brown K, Conway D, Hulme M (2003) Adaptation to climate change in the developing world. Progr Dev Stud 3:179-195

Adger WN, Arnell NW, Tompkins EL (2005) Successful adaptation to climate change across scales. Glob Environ Change 15:77-86

African Forest Forum (2009) A platform for stakeholders in African Forestry

Agrawal A (2008) The role of local institutions in adaptation to climate change. International Forestry Resources and Institutions Program \#W08I-3:1-45

Agrawal A, Chatre A, Hardin R (2008) Changing governance of the world's forests. Science 320:1460-1462

Angelsen A (ed) (2008) Moving ahead with REDD: issues, options and implications. CIFOR, Bogor

Annecke W (2002) Climate change, energy-related activities and the likely social impacts on women in Africa. Int J Global Environ Issues 2:206-222

Bonan GB (2008) Forests and climate change: forcings, feedbacks, and the climate benefits of forests. Science 320:1444-1449

Brown D, Seymour F, Peskett L (2008a) How do we achieve REDD co-benefits and avoid doing harm? In: Angelsen A (ed) Moving ahead with REDD: issues, options and implications. CIFOR, Bogor, pp 107-118

Brown HCP, Buck L, Lassoie JP (2008b) Governance and social learning in the management of non-wood forest products in community forests in Cameroon. Int J Agr Resour Govern Ecol 7:256-275

Carlsson L, Sandstrom A (2008) Network governance of the commons. International Journal of the Commons 2:33-54

Commission des Forêts D'Afrique Centrale (COMIFAC) (2008) Déclaration de Bangui, Commission des Forêts D'Afrique Centrale, Bangui

Commission des Forêts d'Afrique Centrale (COMIFAC) (2009a) Atelier régional REDD, Kinshasa 27-30 janvier, 2009: Documents et Conclusions de l'atelier

Commission des Forêts d'Afrique Centrale (COMIFAC) (2009b) Convention Cadre des Nations Unies sur les Changements Climatiques (SBSTA 30): Soumission des vues des pays du Bassin du Congo, Commission des Forêts d'Afrique Centrale (COMIFAC)

Commission des Forêts d'Afrique Centrale (COMIFAC) (2009c) L'étude de faisabilité sur la pérennité de l'Observatoire des Forêts d'Afrique Centrale (OFAC) est lancée

Congo Basin Forest Partnership (2006) The forests of the Congo Basin: state of the forest 2006

Cotula L, Mayers J (2009) Tenure in REDD: start-point or afterthought? International Institute for Environment and Development, London

Diaw MC (1997) Si, Nda Bot and Ayong: shifting cultivation, land use and property rights in Southern Cameroon. Report No. 21e, Rural Development Forestry Network

Dixon RK, Smith J, Guill S (2003) Life on the edge: vulnerability and adaptation of African ecosystems to global climate change. Mitig Adapt Strat Glob Change 8:93-113

Eastaugh C (2008) Adaptations of forests to climate change: a multidisciplinary review. Report No. IUFRO Occasional Paper No. 21, IUFRO Secretariat, Vienna

Fry I (2008) Reducing emissions from deforestation and forest degradation: opportunities and pitfalls in developing a new legal regime. RECIEL 17:166-182

Gupta J (2008) Global change: analyzing scale and scaling in environmental governance. In: Young OR, King LA, Schroeder H (eds) Institutions and environmental change: principal findings, applications, and research frontiers. MIT, Cambridge, pp 225-258

Hare B, Macey K (2008) Tropical deforestation emission reduction mechanism: a discussion paper, Greenpeace

Hoare AL (2007) Clouds on the horizon: the Congo Basin forests and climate change. The Rainforest Foundation, London

Humphreys D (2008) The politics of 'Avoided Deforestation': historical context and contemporary issues. Int For Rev 10:433-442

Intergovernmental Panel on Climate Change (IPCC) (2007a) Climate change 2007: impacts, adaptation and vulnerability. Contribution of working group II to the fourth assessment report of the intergovernmental panel on climate change. Cambridge University Press, Cambridge

Intergovernmental Panel on Climate Change (IPCC) (2007b) Climate change 2007: synthesis report. Cambridge University Press, Cambridge

Keskitalo ECH (2004) A framework for multi-level stakeholder studies in response to global change. Local Environ 9:425-435

Koch IC, Vogel C, Patel Z (2007) Institutional dynamics and climate change adaptation in South Africa. Mitig Adapt Strat Glob Change 12:1323-1339

Kotto-Same J, Woomer PL, Appolinaire M, Zapfack L (1997) Carbon dynamics in slash and burn agriculture and land use alternatives of the humid forest zone in Cameroon. Agric Ecosyst Environ 65:245-256 
Locatelli B, Kanninen M, Brockhaus M, Colfer CJP, Murdiyarso D, Santoso H (2008) Facing an uncertain future: How forests and people can adapt to climate change. Forest Perspectives No. 5, CIFOR, Bogor, Indonesia

Luttrell C, Schreckenberg K, Peskett L (2007) The implications of carbon financing for pro-poor community forestry, Forestry Briefing 14 Forest Policy and Environment Programme. Overseas Development Institute, Forestry Briefings Series, London, pp 1-5

Mbatu RS (2009) Forest policy analysis praxis: modelling the problem of forest loss in Cameroon. Forest Policy and Economics 11:26-33

Ministry of the Environment and Nature Protection (MINEP) of the Republic of Cameroon (2008) The Forest Carbon Partnership Facility (FCPF) Readiness Planning Idea Note (R-PIN), Yaounde, Cameroon

O'Riordan T, Jordan A (1999) Institutions, climate change and cultural theory: towards a common analytical framework. Glob Environ Change 9:81-93

Orindi VA, Murray LA (2005) Adapting to climate change in East Africa: a strategic approch. IIED, London

Ostrom E (2005) Understanding institutional diversity. Princeton University Press, Princeton

Oyono PR (2004a) Institutional deficit, representation, and decentralized forest management in Cameroon. In: Ribot JC (ed) Environmental governance in Africa working papers. World Resources Institute, Washington, pp 1-36

Oyono PR (2004b) One step forward, two steps back? Paradoxes of natural resources management decentralisation in Cameroon. J Mod Afr Stud 42:91-111

Oyono PR (2005) Profiling local-level outcomes of environmental decentralizations: the case of Cameroon's forests in the Congo Basin. J Environ Dev 14:1-21

Pahl-Wostl C (2009) A conceptual framework for analysing adaptive capacity and multi-level learning processes in resource governance regimes. Glob Environ Change 19:354-365

Parker C, Mitchell A, Trivedi M, Mardas N (2009) The little REDD book, 2nd edn. Global Canopy Programme, Oxford

Patton MQ (2002) Qualitative research and evaluation methods. Sage, Thousand Oaks

Pielke RAJ (1998) Rethinking the role of adaptation in climate policy. Glob Environ Change 8:159-170

Republic of Cameroon (2003) Poverty reduction strategy paper. The World Bank, Washington

Richards M, Jenkins M (2007) Potential and challenges of payments for ecosystem services from tropical forests, Forestry Briefing 16 Forest Policy and Environment Programme. Overseas Development Institute, Forestry Briefing Series, London, p 8

Rights and Resources Initiative (2008) Seeing people through the trees: scaling up efforts to advance rights and address poverty, conflict and climate change, Rights and Resources Initiative, Washington, DC

Robledo C, Forner C (2005) Adaptation of forest ecosystems and the forest sector to climate change. Food and Agriculture Organization of the United Nations, Rome

Ruiz Pérez M, Ndoye O, Eyebe A, Puntodewo A (2000) Spatial characterisation of non-timber forest products markets in the humid forest zone of Cameroon. Int For Rev 2:71-83

Seppälä R, Alexander B, Katila P (2009) Adaptation of forests and people to climate change: a global assessment report. Report No. IUFRO World Series, vol 22. International Union of Forestry Research Organizations (IUFRO), Helsinki

Shackleton S, Shanley P, Ndoye O (2007) Invisible but viable: recognising local markets for non-timber forest products. Int For Rev 9:697-712

Smit B, Pilifosova O (2001) Adaptation to climate change in the context of sustainable development and equity. In: McCarthy JJ, Canziani OF, Leary NA, Dokken DJ, White KS (eds) Climate change 2001: impacts, adaptation, and vulnerability - contribution of working group II to the third assessment report of the intergovernmental panel on climate change, vol 18. Cambridge University Press, Cambrige, pp 876-912

Smit B, Pilifosova O (2003) From adaptation to adaptive capacity and vulnerability reduction. In: Smith J, Klein RTJ, Huq S (eds) Climate change, adaptive capacity and development. Imperial College Press, London, pp 9-28

Smit B, Wandel J (2006) Adaptation, adaptive capacity and vulnerability. Glob Environ Change 16:282-292

Smith JB, Lenhart SS (1996) Climate change adaptation policy options. Clim Res 6:193-201

Streck C, Robert OS, Janson-Smith T, Tarasofsky R (eds) (2008) Climate change and forests: emerging policy and market opportunities. Royal Institute of International Affairs, London

The World Bank (2004) Sustaining forests: a development strategy. The World Bank, Washington

The World Bank (2008a) Forests sourcebook: practical guidance for sustaining forests in development cooperation. The World Bank, Washington

The World Bank (2008b) High demand prompts Forest Carbon Partnership Facility to expand beyond original 20 developing countries. The World Bank

Thompson I, Mackey B, McNulty S, Mosseler A (2009) Forest resilience, biodiversity, and climate change. A synthesis of the biodiversity/resilience/stability relationship in forest ecoystems. Secretariat of the Convention on Biological Diversity, Montreal 
Thynne I (2008) Climate change, governance and environmental services: institutional perspectives, issue and challenges. Public Adm Dev 28:327-339

Tompkins EL, Adger WN (2004) Does adaptive management of natural resources enhance resilience to climate change? Ecol Soc 9:10

UNFCCC (2009) Clean development mechanism registry. UNFCCC

UNFCCC (2010) The list of least developed countries

United Nations Environment Program (UNEP) (2008) CASCADE - Africa Project Brief. In: Facility FGE (ed) UNEP, p 2

Vabi MB, Ngwasiri CN, Galega PT, Oyono RP (2000) The devolution of forest management responsibilities to local communities: context and implementation hurdles in Cameroon. World Wide Fund for Nature, Cameroon Programme Office, Yaoundé

Van den Berg J, Biesbrouck K (2000) The social dimensions of rainforest management in Cameroon: issues for co-management. The Tropenbos-Cameroon Program, Kribi

Visseren-Hamakers I, Glasbergen P (2007) Partnerships in forest governance. Glob Environ Change 17:408419

Walker B, Gunderson L, Kinzig A, Folke C, Carpenter S, Schultz L (2006) A handful of heuristics and some propositions for understanding resilience in social-ecological systems. Ecol Soc 11:13

Weber EP, Khademian AM (2008) Wicked problems, knowledge challenges, and collaborative capacity builders in network settings. Public Administration Review March-April 2008:334-349

Whiteman A, Lebedys A (2006) The contribution of the forestry sector to African economies. Int For Rev $8: 31-43$ 